Wirginia Aksztejn, Pawet Swianiewicz, Katarzyna Szmigiel-Rawska

Uniwersytet Warszawski

Wydziat Geografii i Studiów Regionalnych

wa.aksztejn@uw.edu.pl,p.k.swianiewicz@uw.edu.pl,k.szmigiel@uw.edu.pl

\title{
Can it be too close? The impact of the proximity of the Polish-German border on local development in Poland in the process of European integration
}

\begin{abstract}
Acknowledgements
Paper was prepared for European Urban Research Association Annual Conference in Tilburg, 2018 - we are grateful for insightful comments from conference participants and Ms. Martyna Olczak for her help with calculations. The research described in the paper was made under the project CIT-IN-Project-II - East German and Polish Cities in the Process of European Integration: Challenges and Opportunities for Cities near the German-Polish Border funded by the German-Polish Science Foundation, led by Prof. Martin Rosenfeld.
\end{abstract}

\begin{abstract}
The aim of this study was to investigate the dynamics of local development in the Polish-German borderland in the process of European integration. Taking the perspective of the economically weaker partner (Poland) and its inner market, fiscal and socio-economic indicators were used to depict both spatial and time dimension of the phenomenon. The analysis showed that the dynamics of local economy, foreign investment and labour market have been changing with the advancement of debordering process and had a non-linear character. Furthermore, the legal barriers earlier imposed by the state border were replaced by other limitations for the new common market - more socio-economic in nature. As a result the immediate neighbourhood of the border was the first beneficiary of the European integration initiated in the nineties and the first to experience its drawbacks.
\end{abstract}

Key words: local economic development, border, European integration, Poland, Germany 


\section{Introduction}

Traditional location theories suggest that cities located near the state borders are disadvantaged in their economic growth potential because border restricts the spatial market area. As a result, border regions have limited economic activity and attract only companies that are satisfied with a small sales area (Hoover 1948, Giersch 1949, Lösch 1954). The newer theories, e.g. New Economic Geography (NEG) (Krugman 1991, Helpman 1998, Fujita et al. 1999) although do not directly refer to the role of border regions, discuss processes related to international economic integration. The process coexists with functional changes of the states' administrative borders. Along with globalisation and economic integration processes, the function of the borders has been changing from a barrier to a filter - postmodernism literature says about a 'process of disappearing' (Newman, Passi 1998, p. 198). On the other hand, ethno-territorial conflicts are observed in many places in the world which exemplifies the hybrid nature of the boundaries (Fall 2005). The economic realm, which is under investigation in this paper, is considered to be the one in which the function of border was reduced to the largest extent in comparison to the social, cultural and political ones (Newman, Passi 1998). The economic integration has different stages itself which influence the characteristics of bordering regions. The influence refers to the range of cooperation which is undertaken by organisations located in those regions. The definitions of border regions range from the different stages of alienation to the different stages of political integration (Martinez 1994, Fall 2005, Szmigiel 2008).

The views in the NEG theory as to whether an increased market has a positive or negative impact on the region's economic development are inconclusive. Domination of both negative and positive effects for local economy development is possible. In the case of border regions, the negative effects of borders opening may be an increased price competitiveness for local companies ("market crowding effect") but opening the new market may also lead to growth and innovations. Hence the process of European integration might drastically change the economic situation of the border regions by changing their position from peripheral one within the domestic market towards more central one within the new common market. The gains from integration can be asymmetrical, not necessarily affecting both sides of the border in the same way and to the same extent (Durand et al. 2017, see also Bröcker 1990, Niebuhr, Stiller 2004). This variation has been confirmed by Barjak \& Heimpold (2000), Heimpold (2003) and Stiller (2004) in their analysis of the economic potential of regions located along the Polish-German border before the enlargement of the EU borders in 2004.

The paper studies the phenomenon using the case of the Polish-German border after 1990. The context we take into consideration is a border region of two very different states in terms of the level of economic development and affluence of citizens. At NUTS 2 level the entities of the German side of the border (Dresden, Brandenburg, Mecklenburg-Vorpommern) attain 84-96\% GDP per inhabitant of the EU-28 average whereas the Polish ones (Lower Silesia, Lubusz, West 
Pomerania) - between $57 \%$ and $76 \%$. Similarly, the primary income per inhabitant in the three German regions is almost one and a half times higher than on the Polish side of the border (European Commission 2018).

From the perspective of the economically weaker partner relying on relatively cheap labour force as the main competitive advantage, the subsequent de-bordering steps leading to a free flow of employees are expected to pose a potential challenge. The analysis emphasises the gradual (step-by-step) character of the de-bordering process with several turning points including:

1. Polish free-trade agreement with the EU in 1991 and agreement about local border traffic in 1992, which enabled passport-free travel and 7-days stay for the residents of border municipalities. This invigorated cross-border integration and trade, e.g. giving rise to shopping tourism. At the same time, the freetrade agreement facilitated cross-border trade at the business-to-business level, reaching beyond the borderland.

2. Polish accession to the EU in 2004 - at first glance, this change could seem the most game-changing moment. However, as we argue, the changing nature of the border was more a process rather than a single change.

3. Poland joining the Schengen zone in 2008.

4. Lifting the restriction related to the labour market in May 2011 by Germany. Before this date, despite entering the Schengen Area, the free flow of employees was not possible. A work permit (Freizügigkeitsbescheinigung) or running German-registered own business were required to work legally in Germany (Bergfeld et al. 2015). In consequence, a significant though challenging to measure the number of Polish employees worked illegally. Secondly, those actively interested in working abroad chose different destinations for job migration such as the UK, Ireland or Sweden which opened their labour markets simultaneously with the EU enlargement.

Therefore - as in the case of the more general process of European integration - also in the thinning of the border there has been no single, universal milestone. Following the changes described in the items above, we try to measure the increase/decrease of selected variables which measure economic growth in the run of four intervals: 2001-2004 (capturing pre-accession period), 2004-2008 (reflecting pre-Schengen period), 2008-2012 (early full- integration period, coinciding with the economic crisis), 2012-2016 (mature integration period). Whenever possible, we supplement the analysis with the data from the decade of $1990^{\text {th }}$ to take into account the deeper historical background - the dynamics of the first years of the Polish economic transformation just after communism collapse and reunification of the German state. In that analysis, we capture both early pre-accession (1990-2000) and late pre-accession (2001-2004) periods.

Our empirical analysis looks at the local development trends from the perspective of the "weaker economic partner" - the regions with the lower level of economic development than the regions on the other side of the border. We ask the following research questions:

- How forceful has been the impact of the subsequent steps in European integration on the local development in the border regions? 
- How has the distance to the border differentiated the dynamics of economic development on the local (municipal) level?

The paper consists of three major parts. The first presents the theoretical framework for our analysis leading to the hypothesis to be tested in the following parts. The second introduces empirical strategy - data sources and their limitation as well as the methods of analysis. The third part presents and discusses the results of our empirical investigation.

\section{Theoretical underpinnings}

There are two paradigmatic assumptions adopted in this paper. The basic one draws on the growth poles theory and states that economic development distribution is unequal in physical space (Perroux 1950, Lösch 1954, Myrdal 1957). The second is that European integration pools national economic systems in one continent-wide system by diminishing an importance of national administrative borders. Lifting the barrier of the border is in line with Wallerstein (2004) claim that economic development builds on the elimination of inefficient political structures (Swianiewicz 2014, p. 247). In consequence, the peripheries may gain a more favourable position within the integrated market, but on the other hand, they become open to new factors from which they were earlier shielded by the state border.

The economic dimension of a state border influences flows of goods, people, and capital. In the border studies, there is a widespread view that border is an economic cost - it influences markets in a way that it raises production costs (Brunet-Jailly 2004). European integration aims for changing "thick" state borders of barrier function towards "thin" borders which are easy to cross in many respects. However, the external border of the EU is to be a "thick" border, and also internal borders vary in a level of their thickness (Haselsberger 2014) and it is changing in time simultaneously to the European integration dynamics.

The paradigmatic view is also that locations closest to the administrative border should benefit most of its porousness (Hansen 1977). However, conclusions drawn from empirical data describing Polish-German border regions are not congruent. Data on population changes suggest that the positive effect is only relevant for large towns, especially German cities specialising in services, but not for Polish municipalities (Heider 2018). Some analyses of the spatial distribution of the FDI inflow (at the beginning of the process) and accumulated value (in successive years of European integration) indicate that it has had a linear dependence on Polish-German border - the closer to the border the higher the investment attractiveness. The only exceptions were major urban agglomeration, and especially Warsaw capital city, attractive for FDI regardless of their distance from the EU border (Domański 2003). The similar trends were identified by studies of the FDI in the Czech Republic (Chidlow, Young 2008). Krätke (2002, p. 125) calls the phenomenon "leapfrogging of the border region" as foreign investors 
tend to ignore special economic zones located in the Polish-German borderland and locate their business in large conurbations.

In the face of inconclusive results, we intend to test the relation between border proximity and selected indicators of local development taking into consideration time vector, i.e. subsequent steps in the de-bordering process.

Taking into consideration the broad work of Zarycki (2000, 2011, 2014 with Warczok) we consider Poland to have been a semi-peripheral country for ages. We follow Zarycki view (2011) and consider border-region as a periphery shaped by internal and external economic and power influences. Before the opening due to European integration, Polish border regions were peripheries of the semi-peripheral country. When the border is open, the border region is still the periphery in the semi-peripheral country, but also the periphery in the broader, continental economic system. Taking the Polish side of the Polish-German border region as an analysed case, we claim the perspective of the peripheral area.

Looking for the potential barriers of border regions development we will draw upon a concept of borders as mechanisms of distantiation by which people create control over processes going around them (van Houtum 2002, p. 44). Borders protect a state's internal market, a territorialised economy. As long as the proximity of a national border has its effect on the regional economy, the economic spaces are bounded by political space which influences internal flows of capital and labour (Krätke 2002). When this influence disappears, border regions are ordered in a world-economy regions hierarchy at their place according to the level of development. We claim that in the economic integration process there are two phases of non-linear bordering processes which take place in the order. The first phase is an equalisation phase when forces of functional economic relations play the dominant role. The second phase is an ordering phase defined by putting border regions (peripheries) in 'their' place in world-economy (Wallerstein 2004).

We describe the essential elements of the integration processes by scrutinising relationships of local development changes with time and space. The paper advances two hypotheses; one refers to the temporal aspect of investigated occurrence and one to the spatial dimension. In both cases, we refer to the inner market situation of the weaker partner, the conclusions for the stronger partner may be very different:

H1. Changing a thick border into a thin border is a nonlinear process with phases of opposite directions of economic effects for the border region in the peripheral country (temporal aspects hypothesis)

H1A. In the early phases of EU integration, the equalisation phase is noted when the region enjoys benefits of integration of the markets

$\mathrm{H} 1 \mathrm{~B}$. Once the process is more advanced, there is the ordering phase, when the border region becomes a base of resources

Following $\mathrm{H} 1$ formulation, we expect that in the mature integration phase influence of a border opening for a weaker economic partner does not concentrate in areas immediately adjacent to the border. The main benefits appear in the areas sufficiently distant from the border, to not suffer from labour market competition 
from the strongest partner, but sufficiently close to enjoy benefits of the extended market. We expect such a zone to be located circa 50 kilometres from the border. $\mathrm{H} 2$. In the mature integration phase, the main impact on local economic development appears in the areas more than $50 \mathrm{~km}$ distant from the border

There are not any convincing theories on a spatial distribution of the market integration effects on the local level. Hence we decided to adopt the inductive method of our research and to base the empirical strategy on the knowledge gathered during qualitative in-depth interviews conducted in the studied region. The hypothesis concerning the threshold distance separating the "too close" area from the optimum distance in which the local economy can scoop all benefits and avoid the downsides of border proximity was inspired by the in-depth interviews with local authorities and entrepreneurs in a border town of Zgorzelec in 2017. They considered the drain of employees in the Polish part of the borderland to be one of the major drawbacks of European integration. It affects the already existing Polish companies (wage pressure, increase in operating costs, deterioration of competitiveness) and discourages new capital from investing in the border municipalities. The inductive and deductive method were combined since the hypothesis formulated as an effect on the inductive method was falsified by the implementation of quantitative methods of analysis.

\section{Empirical strategy}

\section{Sources of data}

The research scheme was initiated by a case study of three Polish border locations: Zgorzelec, Szczecin and Świebodzin. The selected locations varied in terms of their size, function and distance from the Polish-German border (from 1,5 km to $56 \mathrm{~km}$ ). The study was based on a desk research analysis and 20 in-depth interviews carried out with representatives of local government, entrepreneurs and business organisations. The interviews - conducted from October to December 2017 - were focused on the perception of the European integration process and its impact on urban development. The key takeaway provided by the qualitative approach was the recurrent theme of pushing forces in the immediate neighbourhood of the border on the Polish side. The drain of labour force - accentuated especially by interviewees in Zgorzelec - was perceived as a severe problem for the local economy. Entrepreneurs stressed the lack of employees, wage pressure and deterioration of competitiveness. Local officials were concerned with investors leapfrogging the borderland in order "have the full circle to recruit employees". The materials collected in the course of this "pilot" stage were then used to formulate the hypothesis and operationalise critical measurements. The verification of the hypotheses was quantitative and was based on official statistics collected for LAU 2 entities. 


\section{Definition of distance}

Though municipalities occupy a fixed territorial location, the question of the proximity measurement is not a trivial one in 25 years perspective we took. Generally speaking, there are two possible approaches to defining the distance to the border: time of travel and distance in kilometres. Although the first method has the appeal of capturing the real effort to reach the border, it also poses severe difficulties in longitudinal analysis. Namely, due to the dynamic development of road network (the total length of motorways alone tripled between 2005 and 2016, Eurostat data) for many municipalities time of travel would not be a stable characteristic defining they proximity to the border in the analysed time. As a consequence, they may fall into different distance ranges throughout the years disrupting the analysis. In our paper, we define the proximity as the distance in kilometres between each municipality's centroids and the border. Having in mind the simplifying character of this method we consider it to be the best-fitted variable for trend analysis.

The selection of distance ranges was guided by the perception of "too close zone" expressed by the respondents in the pilot case study. In the course of the analysis, we investigated narrower and broader intervals in order to confront respondents' perception with the empirical data, finally concluding that a more detailed distance categorisation than every $50 \mathrm{~km}$ does not bring sufficiently more insightful results to justify the over-complication of the general picture.

\section{Municipalities in the scope of the study}

Spatial analysis needs to be based on a criterion of the basic field size. The discussion of distances from the border having a meaning for occurrences distribution is not frequent in the literature, and none of them gives a pattern for this research. For example, there is an analysis of press in which authors are answering the question on the probability of higher interest in immigration issues in dependence on the distance from the US-Mexican border. There are different distances adopted in this study, but each of them is longer than 100 kilometres (Branton, Dunaway 2015).

As our analysis focuses on the Polish-German border, we restrict the investigated population to the municipalities located in the western part of Poland in Lower Silesia, Kujawy-Pomerania, Lubusz, Opole, Pomerania, Greater Poland, West-Pomerania regions. This selection offers a significant diversification of proximity to the German border - ranging from a little more than $1 \mathrm{~km}$ to $345 \mathrm{~km}$. The upper range of this interval seems to be a value for which we can reasonably expect a lack of direct influence of the border. By contrast, including more regions could introduce the impact of the eastern border and the specifics of less-developed eastern regions into the model ${ }^{1}$.

Lower Silesia and Opole regions border with Polish southern neighbour: the Czech Republic. However, due to the less intensive economic bounds we consider this borderland less important than the Polish-German one. As an illustration we may use foreign trade commodity turnover 


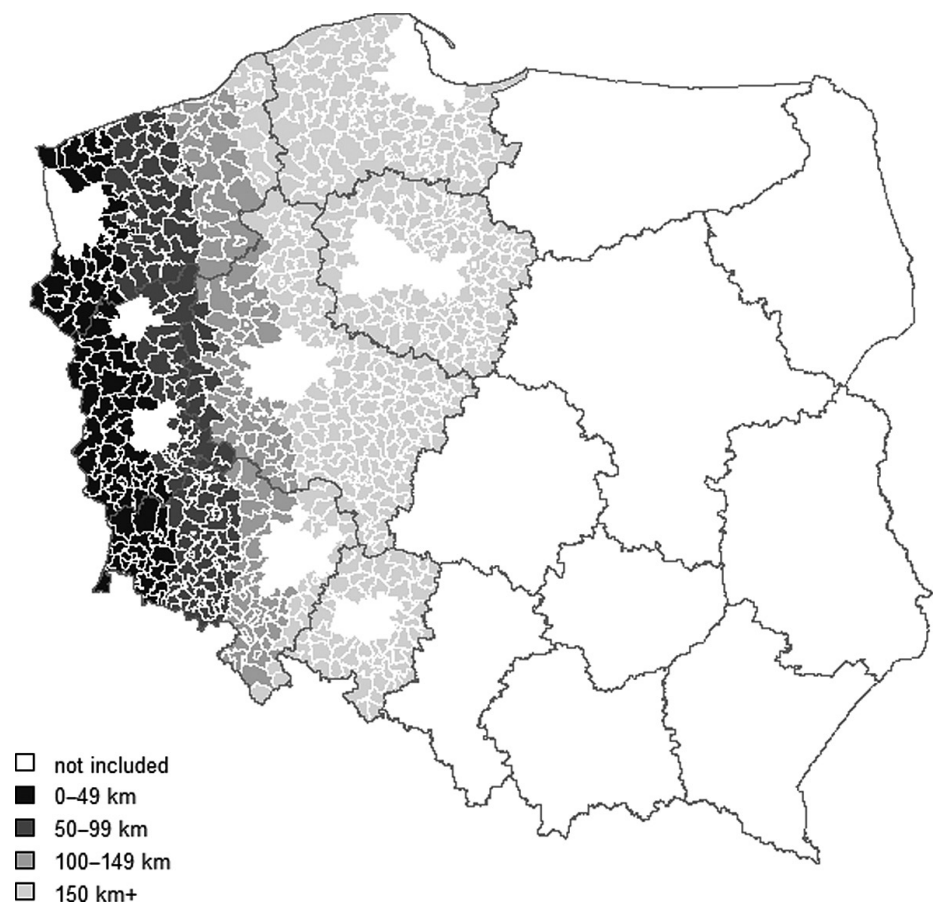

Fig. 1. Investigated municipalities with distance ranges

In the course of analysis, we also decided to exclude functional metropolitan areas - assuming that their development has the dynamics of its own and may skew the results for other localities within the same distance ranges. As a result of decisions concerning distance ranges and municipality types, the final sample consisted of 824 observations.

\section{Variables in the scope of the study}

The selection of variables used for testing the temporal and distance hypothesis encountered some challenges. Firstly, we needed data available at the level of municipalities (LAU 2) to be able to define precise distances from the border. Secondly, long time series were required: reaching back at least to 2001 to cover the pre-accession period but preferably to the nineties to consider an early pre-accession period. Thirdly, as we were primarily interested in a comparison of economic development indicators between the border proximity categories we needed a measure that would set aside the primary differences in economic development and the magnitude of changes within the given period resulting from general trends or external factors. For these reasons, values used in the analysis

(2017): in terms of export the share of Germany accounted for $27.5 \%$ and import (based on country of origin) $-23.1 \%$, making our western neighbour the most important business partner. The figures for the Czech Republic are: $6.4 \%$ and 3.6\% respectively (Central Statistical Office 2018). 
express the change between the beginning and the end of the given time interval for each distance category put into perspective of general change:

$$
\frac{\Delta w_{i j}}{\Delta w_{j}}
$$

where the $\Delta w$ is the change in the value of an indicator, $i$ is the distance category, and $j$ is an investigated period. To sum up, we interpret the above-average positive dynamics of the indicator as a stronger response of the given distance category to the growth impulse provided by a particular integration milestone.

We investigate three types of indicators which measure various aspects of the local development. Firstly, a tax base of a local property tax (PT) from legal entities is used as an approximation of the development of economic activity. Property tax from legal entities is determined by the council of each municipality. The Law on Local Fees and Taxes specifies only the maximum allowable rates. Moreover, municipalities can introduce exemptions from PT, therefore in the analysis we used data taking into account the consequences of these exemptions. Polish property tax is not directly related to the value of properties, but it is based on a flat rate per square meter of the property of the pre-defined categories. Therefore the increasing tax base is merely a result of the new investments increasing the number of taxable square metres, and therefore it reflects the new investments in the local economy. The alternative considered measure was the number of registered companies, however it suffers several weaknesses. First, the variable is based on the National Business Registry and along with the virtue of being a direct measure has the disadvantage of including firms who are not active though still registered. Second, it is based on place of registration, so it disregards economic activity taking place in the studied region if the company registered in another municipality undertakes it.

The second type of variables focuses on the number of companies with foreign capital per 10 thousand citizens in productive age. This variable is meant as an indicator of pulling power of the borderland not only for the domestic market but for foreign investors as well. The data enables to present only the general number of companies. The information about the origin of the capital is not available at the level of municipalities. Basing on this data we cannot claim with certainty that the foreign investments have come from the other side on the Polish-German border in the process of cross-border market integration. However, judging from the generally high share of the German capital in the Polish economy (19.1\% of foreign investment in 2015 - Polityka Insight 2017) and the distinctive presence of German companies in Special Economic Zones located at the border (e.g. 22 out of all 53 companies in Legnicka Special Economic Zone in 2018) we may expect such phenomenon to be present. Furthermore the influx of non-German, foreign companies should also be considered an indicator of the growing attractiveness of the Polish-German border zone. The limitation of this variable relates to changes in formal requirements in the process of registering in the National Business Registry and makes the data for 2014-2016 not fully comparable 
with the previous periods in terms of data accuracy (since 2014 companies may not report information about the expected number of employees, prevalent activity and form of ownership).

Lastly, we analyse the situation on the labour market in order to explore the hypothesis about the worsening situation of employers on the Polish side of the borderland. From the perspective of entrepreneurs, the low unemployment rate means potential problems with finding skilled and motivated employees and wage pressure. We used data available at the level of municipalities, namely the share of the officially registered unemployed in the population in productive age. This variable has, however, two shortcomings. The first one is strictly technical: the available time series extends only from 2003 till 2016 which gives no insight into pre-accession periods. The second drawback refers to the question of an adequate description of the labour market situation this variable provides. Clearly, it does not capture illegal (i.e. not registered) work and the unregistered unemployment. The impact of these two phenomena on the availability of employees on the local labour market is difficult to assess.

We find all these drawbacks as significant limitations which we overcome by data range concerning different segments of local economy description. We consider them as not disruptive enough to resign on the analysis of the local economy since only local level analysis allows for verification of spatial distribution of the economic integration effects. It also makes temporal analysis much more detailed than regional or state level analysis.

\section{The results}

\section{Development of economic activity}

The relative change in PT from legal entities is among variables generating the strongest effect of border proximity, however, the significance of the border seems to fade away with time. At the early pre-accession stage we observe the strongest relative increase in the closest neighbourhood of the border (up to $50 \mathrm{~km}$ ), whereas in the period just preceding the EU enlargement - the tendency reverses giving the upper hand to the areas more remote from the border. The next integration milestone - the accession in 2004 - initiated acceleration of development in the border region which lasted until 2008. Despite another facilitation for the free flow of people - entering the Schengen Area - in the next 5-year period there are almost no differences in the dynamic of PT development between border distance ranges. The impact of this milestone could be of lesser significance for the development of the local business due to the fact that it still was not followed by the opening of the German labour market which would induce intensified cross-border job migrations and by this means cause wage pressure or drain of employees in the Polish part of the borderland. The later phenomena can be rather indirectly observed in the years 2012-2016 - in the below-average PT development in the border region. 


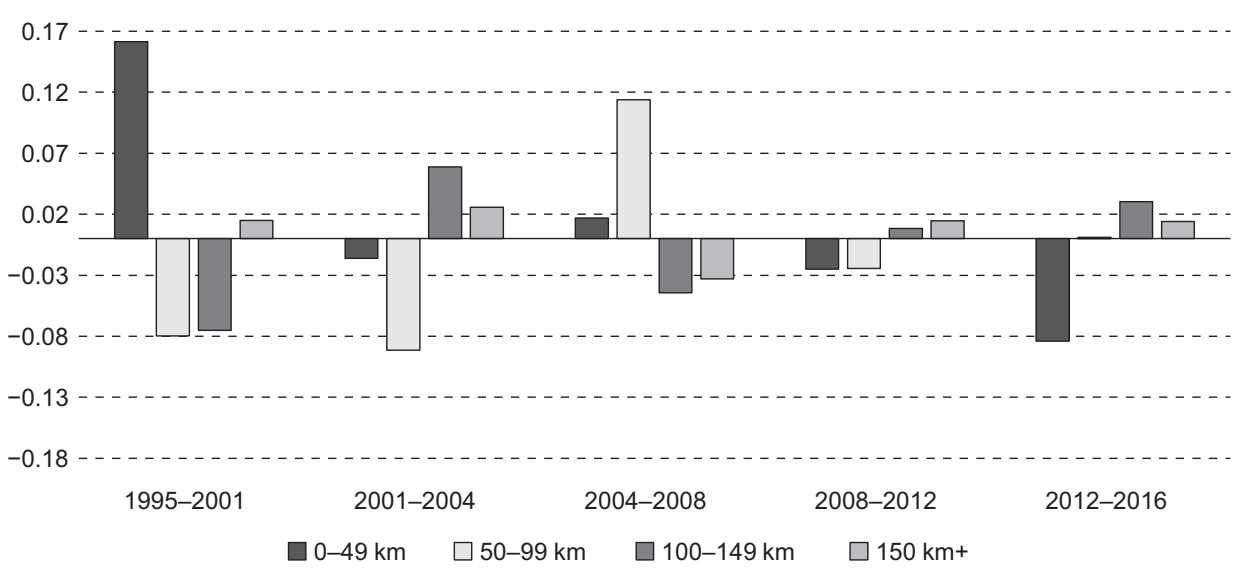

Fig. 2. Relative change in PT from legal entities

\section{Development of entities with foreign capital}

Throughout the whole investigated period the number of entities with foreign capital per capita has been higher in the neighbourhood of the Polish-German border than in the more interior municipalities and since the nineties, this indicator has generally been growing in all distance categories. In the early pre-accession period we can observe a more rapid growth rate just next to the border, but with time the differences tend to get smaller and more often the 100-149 km zone is favoured. The data suggests that the real breakthrough and acceleration in foreign investors' influx at the border took place before the official accession (Fig. 3). Although the implementation of the European regulations surely facilitated cooperation, the economic incentives seem to have been sufficient to venture into entering the Polish market. As expressed by one of the local officials

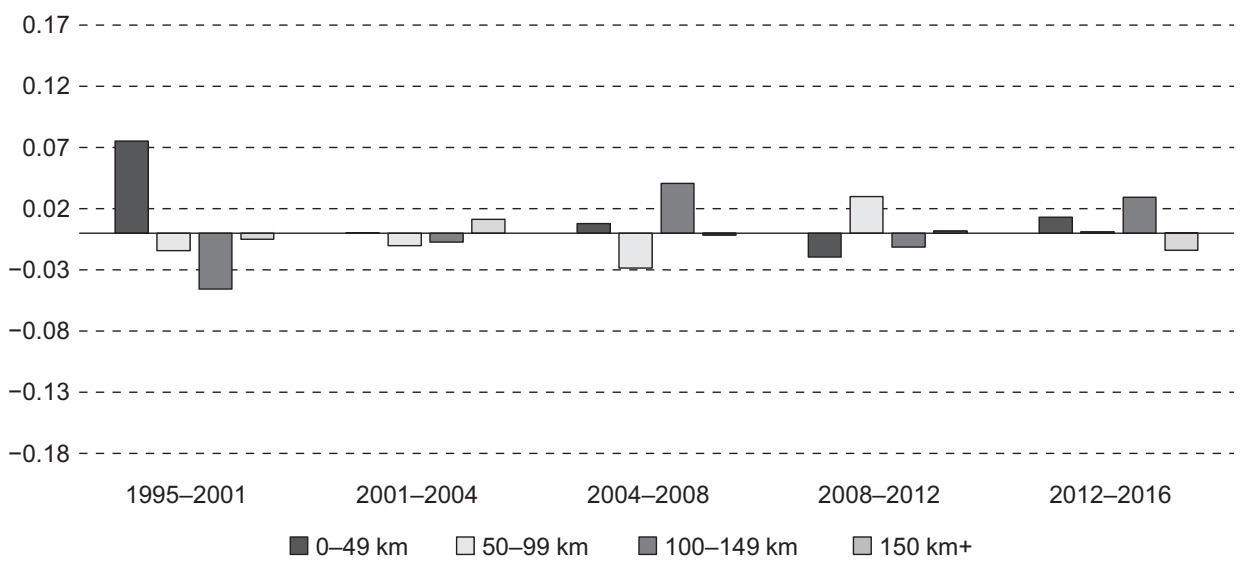

Fig. 3. Relative change in the number of entities with foreign capital registered in National Business Registry per 10 thousand citizens in the productive age 
in Zgorzelec the key for cooperation is the perception of mutual interest: "Here trade has always been present. Those who cooperate with the Germans have been doing it for ages. Some of them have even already ended the cooperation".

\section{The decrease in the unemployment rate}

As stated earlier the analysis of unemployment data is one of the most complicated due to difficulties with capturing real practices by official data. Furthermore, the time series available for analysis does not allow to follow the trends in a broader perspective. Nevertheless, the improvement in the borderland labour market is noticeable. In the course of 14 years, the $0-49 \mathrm{~km}$ zone has converted from a disadvantaged zone into a leader of the low unemployment rate (Table 1). Although the changes in the immediate border zone are in line with general trends in the investigated area - i.e. progressing decrease in the unemployment rate interrupted by the crisis of 2008, the effects of the economic breakdown were mitigated by the opening of the German labour market in 2011.

Table 1. Basic characteristics of investigated distance ranges

\begin{tabular}{lccccccc}
\hline \multirow{2}{*}{$\begin{array}{c}\text { Distance } \\
\text { range }\end{array}$} & $\begin{array}{c}\text { Number of } \\
\text { municipalities }\end{array}$ & $\begin{array}{c}\text { Property tax from } \\
\text { legal entities per } \\
\text { capita* }\end{array}$ & $\begin{array}{c}\text { Number of foreign } \\
\text { Investigated area=1 }\end{array}$ & $\begin{array}{c}\text { Rempanies per 10 K* } \\
\text { Investigated area }=1\end{array}$ & $\begin{array}{c}\text { Registered unem- } \\
\text { ployment rate } \\
\text { Investigated area=1 }\end{array}$ \\
\cline { 2 - 8 } & & 1995 & 2016 & 1995 & 2016 & 2004 & 2016 \\
\hline $0-49 \mathrm{~km}$ & 99 & 1.20 & 1.21 & 1.91 & 2.06 & 1.07 & 0.89 \\
$50-99 \mathrm{~km}$ & 133 & 1.17 & 1.19 & 1.37 & 1.34 & 1.00 & 1.00 \\
$100-149 \mathrm{~km}$ & 124 & 0.94 & 0.91 & 1.14 & 1.15 & 0.97 & 0.91 \\
$150 \mathrm{~km}+$ & 468 & 0.94 & 0.93 & 0.66 & 0.66 & 1.00 & 1.05 \\
\hline In total & 824 & 1 & 1 & 1 & 1 & 1 & 1 \\
\hline
\end{tabular}

*In productive age.

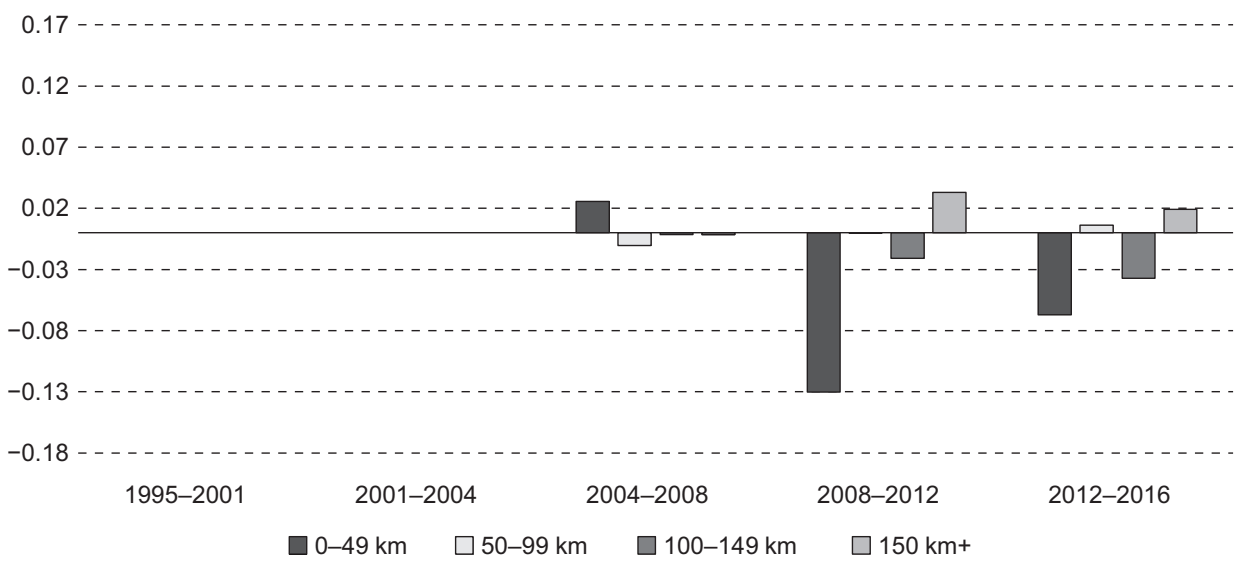

Fig. 4. Relative change in the registered unemployment rate 
Also in terms of the relative change in the unemployment rate (Fig. 4) there is a noticeable advantage of the $0-49 \mathrm{~km}$ zone in reducing the unemployment rate (as the unemployment rate is a negative variable the interpretation of the figure needs to be reversed). The intensification of a decrease in the unemployment rate begun with post-Schengen period and - in more moderate extend - continued after 2012.

\section{Discussion}

The analysed data provides encouraging support for the proposed hypotheses. Especially the analysis of the property tax from legal entities offered a sensitive measure of local development and revealed the greatest variation in the growth dynamics between the considered distance ranges. In the relative change of local PT amount we observe both equalisation and ordering phases (H1) as well as signs of a slowdown in the municipalities located just at the Polish-German border in the most recent period $(\mathrm{H} 2)$.

In favour of timeline hypothesis (H1) we contend that the significance of the border proximity was the greatest up to 2008 , especially in the early pre-accession period of the nineties. It suggests that the Association Agreement between Poland and the UE and favourable currency exchange rates invigorated the economy in the borderland despite the legal and administrative obstacles. The milestones such as the Association Agreement or the EU accession influenced at first the most immediate neighbourhood of the border, however, the effect was not durable and the tendency reversed for the advantage of the more central regions after several years. As a matter of fact, we observe that the most immediate border neighbourhood was the leader of growth dynamics only in the early pre-accession period and afterwards only once attained above-average increase. Hence, the benefiting zone very quickly moved to the interior.

The PT data confirms to some extent the subjective observation of the respondents that presently the border pushes the business away (H2). Indeed within the $0-49 \mathrm{~km}$ distance, the increase in the value of collected property tax is the lowest. Nevertheless, the postulated $50-99 \mathrm{~km}$ zone cannot be termed an entrepreneurialism sweet spot as more central regions have been growing at no slower or even faster pace.

The analysis of the companies' number with foreign capital supports our argumentation in favour of $\mathrm{H} 1$ and exhibits even less durable benefit of the immediate border zone. For this variable, we observe that in the borderland the EU accession was not the strongest impulse for development. The underappreciated role of spontaneous entrepreneurialism and profit-driven ventures demonstrates itself in a rapid increase of foreign investors in the earliest pre-accession period. In line with Krätke (2002) we conclude that the border zone intensely attracted foreign capital only in the nineties, and later investors "leapfrogged" the borderland and moved their interest inland lured by more urbanised and industrialised areas. As our data excludes functional areas of metropolises the conclusion is 
even stronger: large conurbation areas are a pulling factor, but the border alone is a sufficient pushing factor. Consequently, the most recent data shows that presently the $0-49 \mathrm{~km}$ zone is not favoured by foreign investors. However, the optimum zone seems to stretch even further than the hypothesis expected $(\mathrm{H} 2)$ - between 100 and $149 \mathrm{~km}$ from the border.

Due to its already described limitations, unemployment data can only play a subsidiary role in explaining borderland phenomena. The lack of a broader time perspective makes it impossible to assess the impact of early integration milestones which turned out to be the most potent in the case of other investigated variables. Fortunately, the data covers the introduction of two legal changes most closely related to the free flow of people: joining the Schengen Area Agreement and opening the German labour market for Polish employees. We observe that the drop in the registered unemployment rate following these milestones was the most noticeable in the immediate border zone. It suggests possible problems resulting from the deficiency of labour force for companies based "too close" and a bit bigger pool of potential employees available in the distance of 50-99 km from the border. Having said that we need to admit that the picture of the labour market based on official data is not complete. As estimated by Cyrus (2009) and Vogel (2012) the number of Poles working illegally in Germany before the opening of the German labour market accounted for 100 thousand and their status captured by the official Polish statistics is not clear. It is also worth noticing that west-bound job migration from Poland to Germany in recent years has been followed by the influx of Ukrainian workers - to some extend alleviating the problem of labour force deficiency. However, changing administrative and legal regulations leading to the opening of the German market for Ukrainians make the situation on the east side of the border very dynamic.

The aspect of analysis worth future investigation is the complexity of economic situation along the Polish-German border. Poland borders with three German regions: Saxony, Brandenburg and Mecklenburg-Vorpommern which differ in terms of economic development, demographic situation and prevalent economic specialisation (as observed in Chojnicki 1999). Our case study analyses suggest that we may observe very different economic incentives and migration processes in these three borderlands. At the extreme ends of the scale we have Szczecin which could easily play a metropolitan role for depopulated, rural Mecklemburg-Vorpommern and north-east Brandenburg and Zgorzelec - lagging behind its twin brother Görlitz and more industrialized vicinities of Dresden. Treating the Polish-German border region not as a single being but three separate borderlands may reveal different dynamics and at the same time - more vivid differences between distance ranges.

Lastly, in our approach, we focused on the description of the Polish domestic market. However, the most holistic analysis of the debordering phenomenon would involve considering the Polish-German borderland as a whole and investigating the impact of the nearest and the most significant development poles in the border area regardless of their "nationality", as well as directions of foreign 
investment flows ${ }^{2}$. It is in line with the assumptions of the growth-pole theory and especially described by Perroux centrifugal, and centripetal forces influences in the growth-pole creation processes (1950) or by Myrdal (1957) spread and backwash effects (p. 27, 31).

\section{Conclusion}

In the course of the investigated period (1995-2016) the Polish border zone generally improved its economic standing, however, the increase was not steady. The most notable growth took place in the nineties. In terms of market-building process, Poland's integration with the EU in 2004 in some respects has more symbolic than practical meaning (cf. Balogh 2014). Economic activity found its ways to build functional relations at the first moment when the Iron Curtain collapsed. Thus the administrative space had a meaning while it built an actual container for economic activity but after the first gap in the container walls occurred the economic activity started to follow the logic of functional spaces.

The analysed data gives evidence of the phenomenon of the equalisation phase: the response of the border region to the stimuli in the form of legal integration milestones is the most immediate. However, the effect of the intensified economic growth in the borderland fades away with time (ordering phase).

Considering the dynamics of economic development, we can also confirm that presently a "too close zone" actually exists. However, the location of optimum distance is difficult to pin down, and contrary to the initial belief the $50-99 \mathrm{~km}$ strip does not stand out as an evident growth leader.

It is worth noticing that the reasons for the deterioration of the growth dynamics in the Polish borderland are twofold. First, the central regions also benefit from the lifting of formal barriers in the process of the European integration at with time their development level and more favourable location in the domestic market translate into more effective absorption of newly-acquired opportunities. Second, the borderland of the weaker partner becomes a resource base for their richer neighbour as well. Although there are no formal barriers to the development of the border region remains restricted - this time by the social (job migration) and economic (operating costs) factors.

The qualitative researched revealed numerous barriers for Polish companies entering German market (German legislation and procedures discouraging small and medium-sized companies, language barrier preventing from entering tenders, weakness of the Polish capital), but also unobvious motivations (label "Made in Germany") and incentives (subsidies and tax exemptions for constructors participating in urban regeneration programmes). 


\section{References}

Barjak F., Heimpold G. 2000. Development Problems and Policies at the German Border with Poland - Regional Aspects of Trade and Investment. European Research in Regional Science, 10: 13-31.

Balogh P. 2014. Perpetual borders: German-Polish cross-border contacts in the Szczecin area. Stockholm University, Stockholm.

Bergfeld A., Nadler R., Sosiński P. 2015. Integracja rynków pracy na polsko-saksońskim obszarze przygranicznym. Rozwój Regionalny i Polityka Regionalna, 32: 45-65.

Branton R.P., Dunaway J. 2015. Spatial Proximity to the U.S. - Mexico Border and Newspaper Coverage of Immigration Issues. Political Research Quarterly, 62(2): 289-302.

Bröcker J. 1990. Räumliche Auswirkungen der europäischen Integration - ein Survey. Jahrbuch für Regionalwissenschaft, 11: 43-63.

Brunet Jailly E. 2004. Toward a model of border studies: What do we learn from the study of the Canadian American border? Journal of Borderlands Studies, 19(1): 1-12.

Central Statistical Office. 2018. Obroty towarowe handlu zagranicznego ogółem i według krajów w 2017 (http://stat.gov.pl/files/gfx/portalinformacyjny/pl/defaultaktualnosci/5466/2/10/1/obroty_towarowe_handlu_zagranicznego_ogolem_i_wg_krajow_w_2017.pdf; accessed: 3.01.2019).

Chidlow A., Young S. 2008. Regional Determinants of FDI Distribution in Poland. William Davidson Institute Working Paper (943) (https://ssrn.com/abstract=1488331; accessed: on 11.04.2019).

Chojnicki Z. 1999. Uwarunkowania rozwoju regionu nadgranicznego - koncepcje i założenia teoretyczne. [In:] Z. Chojnicki, Podstawy metodologiczne i teoretyczne geografii. Bogucki Wydawnictwo Naukowe, Poznań, pp. 355-377.

Cyrus N. 2009. Undocumented migration. Counting the uncountable. Data and trends across Europe. Country report Germany. Hamburger Institut für Sozialforschung, Hamburg.

Domański B. 2003. Industrial Change and Foreign Direct Investment in the Postsocialist Economy. The Case of Poland. European Urban and Regional Studies, 10(2): 99-118.

Durand F., Decoville A., Knippschild R. 2017. Everything All Right at the Internal EU Borders? The Ambivalent Effects of Cross-Border Integration and the Rise of Euroscepticism. Geopolitics, DOI: 10.1080/14650045.2017.1382475.

European Commission. 2018. Eurostat Regional Yearbook (https://ec.europa.eu/eurostat/documents/3217494/9210140/KS-HA-18-001-EN-N.pdf/655a00cc-6789-4b0c-9d6d-eda24d412188; accessed: 11.01.2019).

Fall J.J. 2005. Drawing The Line: Nature, Hybridity And Politics In Transboundary Spaces. Border Regions Series. Ashgate, Abington, UK.

Fujita M., Krugman P., Venables A. 1999. The Spatial Economy: Cities, Regions and International Trade. MIT Press, Cambridge.

Giersch H. 1949. Economic Union between Nations and the Location of Industries. The Review of Economic Studies, 17: 87-97.

Hansen N. 1977. Border regions: A critique of spatial theory and a European case study. The Annals of Regional Science, 11(1): 1-14.

Haselsberger B. 2014. Decoding borders. Appreciating border impacts on space and people. Planning Theory \& Practice, 15(4): 505-526.

Heider B. 2018. The impact of EU Eastern enlargement on urban growth and decline: New insights from Germany's Eastern border. Papers in Regional Science, DOI:10.1111/pirs.12407.

Heimpold G. 2003. Zur Ausstattung der deutschen Regionen entlang der Grenze zu Polen mit wichtigen Wachstumsfaktoren. Wirtschaft im Wandel, 7: 215-221.

Helpman E. 1998. The Size of Regions. [In:] D. Pines, E. Sadka, I. Zilcha (eds.), Topics in Public Economics - Theoretical and Applied Analysis. Cambridge University Press, Cambridge, pp. 33-45.

Hoover E.M. 1948. The Location of Economic Activity. McGraw-Hill, New York.

Van Houtum H. 2002. Borders of Comfort: Spatial Economic Bordering Processes in and by the European Union. Regional \& Federal Studies, 12(4): 37-58.

Krätke S. 2002. Cross-Border Cooperation and Regional Development in the German-Polish Border Area. [In:] M. Perkmann, M.N. Sum (eds.), Globalization, Regionalization and Cross-Border Regions. Palgrave Macmillan UK, London, pp. 125-147.

Krugman P. 1991. Increasing returns and economic geography. Journal of Political Economy, 99: 483499. 
Lösch A. 1954. Economics of location. Yale University Press, New Haven.

Martinez O.J. 1994. The dynamics of border interaction. New approaches to border analysis. [In:] C.H. Schofield (ed.), Global Boundaries. World boundaries. Vol. I. Routledge, London-New York, pp. 1-15.

Myrdal G. 1957. Rich Lands and Poor: The Road to World Prosperity, World Perspectives. Harper and Row, New York-Evanston.

Newman D., Paasi A. 1998. Fences and neighbours in the postmodern world: boundary narratives in political geography. Progress in Human Geography, 22(2):186-207.

Niebuhr A., Stiller S. 2004. Integration effects in border regions - a survey of economic theory and empirical studies. Jahrbuch für Regionalwissenschaft, 24(1): 3-21.

Perroux F. 1950. Economic Space: Theory and Applications. The Quarterly Journal of Economics, 64(1): 89-104.

Polityka Insight. 2017. Co przyniosły inwestycje zagraniczne. Wpływ na gospodarkę Polski w ostatnim ćwierćwieczu (https://www.politykainsight.pl/_resource/multimedium/20109315; accessed: 19.05.2018).

Stiller S. 2004. Integration in the German-Polish Border Region - Status Quo and Potential. Argumenta Oeconomica, 15(1): 31-56.

Swianiewicz J.J. 2014. Możliwość makrohistorii: Braudel, Wallerstein, Deleuze. Monografie Fundacji na rzecz Nauki Polskiej. Wydawnictwo Naukowe Uniwersytetu Mikołaja Kopernika, Toruń.

Szmigiel K., 2008. Relacje, konkurencja, współpraca. Próby znalezienia właściwych definicji dla działań podejmowanych na arenie międzynarodowej przez regiony administracyjne. [In:] D. Ilnicki, K. Janc (eds.), Przekształcenia regionalnych struktur funkcjonalno-przestrzennych. Instytut Geografii i Rozwoju Regionalnego Uniwersytetu Wrocławskiego, Wrocław, pp. 47-54.

Vogel D. 2012. Update report Germany: Estimate number of irregular foreign residents in Germany (2010), Database on Irregular Migration (http://irregular-migration.net/fileadmin/irregular-migration/dateien/4.Background_Information/4.5.Update_Reports/Vogel_2012_Update_report_ Germany.pdf; accessed: 19.05.2018).

Wallerstein I. 2004. World-Systems Analysis. An Introduction. Duke University Press, Durham-London.

Warczok T., Zarycki T. 2014. Bourdieu recontextualized: Redefinitions of western critical thought in the periphery. Current Sociology, 62(3): 334-351.

Zarycki T. 2000. Politics in the periphery: Political cleavages in Poland interpreted in their historical and international context. Europe-Asia Studies, 52(5): 851-873.

Zarycki T. 2011. Peryferie czy pogranicza? Krytyczne spojrzenie na współczesne sposoby posługiwania się pojęciem „pogranicza”. [In:] B. Jałowiecki, S. Kapralski (eds.), Peryferie i pogranicza: O potrzebie różnorodności. Wydawnictwo Naukowe Scholar, Warszawa, pp. 33-54.

\section{Czy może być za blisko? Wpływ odległości od granicy polsko- niemieckiej na rozwój polskich gmin w procesie integracji europejskiej}

Zarys treści: Celem artykułu jest zbadanie dynamiki rozwoju lokalnego na pograniczu polsko-niemieckim w procesie integracji europejskiej. Przyjmując perspektywę słabszego ekonomicznie partnera (Polski) i jego rynku wewnętrznego, użyto wskaźników socjoekonomicznych i podatkowych, aby zobrazować zarówno przestrzenny, jak i czasowy charakter występujących tam zjawisk. Analiza wykazała, że dynamika lokalnego rynku, inwestycji zagranicznych oraz rynku pracy zmieniała się wraz z procesem zacierania się granicy i miała charakter nieliniowy. Co więcej, bariery prawne wcześniej narzucane przez granicę państwową zostały zastąpione innymi ograniczeniami nowego, wspólnego rynku o bardziej społeczno-ekonomicznym charakterze. W konsekwencji najbliższe sąsiedztwo granicy stało się pierwszym beneficjentem integracji europejskiej zapoczątkowanej w latach 90., ale również pierwsze doświadczyło jej negatywnych stron.

Słowa kluczowe: lokalny rozwój ekonomiczny, granica, integracja europejska, Polska, Niemcy 